\title{
IAMJ
}

INTERNATIONAL

AYURVEDIC

MEDICAL JOURNAL

\section{THE EVALUATION OF BACTERIOLOGY IN PRE - POST KSHARA KARMA OF PERIANAL ABSCESS - A CASE REPORT}

\author{
Hiremath Sangamesh ${ }^{1}$, Biradar Vijaykumar ${ }^{2}$ \\ ${ }^{1} \mathrm{PhDScholar},{ }^{2}$ Professor, \\ Dept of Shalya Tantra, NK Jabshetty Ayurveda Medical College and Hospital, Bidar, Karnataka, India
}

Corresponding Author: drsangameshsh@gmail.com

https://doi.org/10.46607/iamj6408102020

(Published online: October 2020)

Open Access

(C) International Ayurvedic Medical Journal, India 2020

Article Received:11/09/2020 - Peer Reviewed:22/09/2020 - Accepted for Publication:24/09/2020

Check for updates

\begin{abstract}
Abscess is a collection of the pus in cavity and it is an acquired condition seen all over the body. The clinical features of abscess are swelling, pain, redness, tenderness, and local temperature. The aggravated Doshas vitiate the skin, blood, muscles, fat and bone tissue, become localised and produce a troublesome swelling - deep rooted, painful, slowly bulging called VIDRADHI. The abscess which is developed in perianal regions is called perianal abscess. Treatment of perianal abscesses requires prompt surgical drainage. However, there is no evidence that uncomplicated perianal abscesses can be safely treated only with drainage. For this reason, it is important to identify the causative organisms in pre- post I\&D Pratisaraniyakshara karma there-fore, we accessed the microbiological analysis of this patient. Here in this case the Ayurvedic management of Pratisaraniyakshara was applied post I and D considering it as a DustaVrana keeping in the mind to avoid the reoccurrence and complication.
\end{abstract}

Keywords: Perianal abscess, Gudhavidradhi, bacterialogy, Pratisaraniyakshara,

\section{INTRODUCTION}

As Abscess is a collection of pus in the body and pyogenic Abscess is the commonest variety of Abscess.
A) Direct infection from outside due to penetrating wounds, B) Local extension from adjacent focus of 
infection, C) Lymphatics, D) Blood stream of hemorrhage. The cardinal features of acute inflammation are usually present. These are rubor (redness), dolor (pain), calor (heat) and swelling (tumor). The suppurative infection gradually leads to cell death and liquification. ${ }^{1}$ The clinical features of Vidradhi presenting swelling, pain, redness, local temperature can be correlated to abscess The aggravated Doshas vitiate the skin, blood, muscles, fat and bone tissue, become localised and produce a troublesome swelling - deep rooted, painful, slowly bulging called Vidradhi. When this Vidradhi completes its Pakwa Avasta, it burst opens or we have to do Bedhana Karma to drain vitiated substances leading to a cavity ${ }^{2}$. The majority of anorectal suppurative disease results from infections of the anal glands (cryptoglandular infection) found in the intersphincteric plane. Their ducts traverse the internal sphincter and empty into the anal crypts at the level of the dentate line. Infection of an anal gland results in the formation of an abscess that enlarges and spreads along one of several planes in the perianal and perirectal spaces. ${ }^{3}$ The stages of treatment of Vranasopha and Vidradhi are similar viz, Amavasta, Pachyamanavasta, Pakvavasta. ${ }^{4}$ Ksharapossess the qualities like Shodana (cleansing) and Ropana (healing). ${ }^{5}$ Hence we planned the application of Pratisarana Kshara in the management of drained abscess cavity, as it enhances the healing property.

Pyogenic infection is characterisized by several local inflammations.it ususally presents with pus formation. These are generally caused by one of the pyogenic bacteria. Pyogenic infection may be endogeneous or exogeneous.the human skin and soft tissue infections are caused by microbial pathogenes. These results in production of pus. Both aerobic and anerobic bacteria have been implicated in infections. Coagulase positive staphylococcus aureushas been found to be more dominant organism in pus.

Antibiotic resistance among bacteria is becoming more and more serious problem throughout the world. It is said that evolution of the bacteria towards resistances to antimicrobial drugs, including multidrug resistances, is unavoidable because it represents a particular aspects of the general evolution of bacteria that is un-stoppable. Antibiotics resistance emerges commonly when patients are treated with empirical antimicrobial drugs. Monitoring of the resistances patterns iin the hospital is needed to overcome these difficulties and to improve the outcomes

This study was designed to evaluate the profile of aerobic pyogenic bacteria in perianal abscess along with their susceptibility to our trial drug.

\section{Case Report}

A 15-year-oldmale patient came to Shalya Tantra OPD at our hospital with.

- Chief complaints of hard mass of swelling around the anus and discomfort in sitting from 12 days. Past history told by patient was previously 6 day before he had severed throbbing pain at perianal region and was associated with tenderness and fever.

- On clinical examination we found externally a large tender mass, skin with red appearance and local temperature and on per rectal digital examination we found a soft tender mass at $3 \mathrm{O}$ clock position in which fluctuation and fluid thrill test were positive and there were no any internal opening found. The mass was completely fixed, and tenderness elicited. After thorough examination and detail history taking, we diagnosed it as perianal abscess. Later the line of treatment was planned to do Incision and drainage followed by Pratisaraniyakshara application under saddle block.

\section{Preoperative Procedure:}

- Patient was nil orally 6 hours before OT

- Enema was given before surgery

- Surgical profile investigations such as CT, BT, $\mathrm{HB} \%$, HIV, HbSAG, RBS, were done

- Consent of the patient,

- Injection Lignocaine test dose and part preparation was done

And the patient was prepared for procedure according to standard protocol.

\section{Operative procedure:}

- Under saddle block with all aseptic precaution in lithotomy posture part painted and draped.

- initially manual dilatation of anal canal by lignocaine jelly. 
- Pus samples were collected during inscion and drainage, the specimens were collected in sterile container or aspirated into sterile syringes and transported to the microbiology laboratory.

- After complete breaking of pus loculi and the cavity was followed by Pratisarinyakshara application for about 60 seconds and Nimbuswarasa wash was given. And finally, the Yastimadu soaked pads were inserted in the cavity followed by anal pack and sterile dressing was applied.

- These samples were processed on suitable culure media and incubated at 37 degree celcius under aeerobic conditions. The organisms were identified by biochemical reactions, Gram stains, motility tests as applicable as per standards operative procedures and interpreted as per $\mathrm{C}$ Clinical Laboratory Standard Institution guidelines.

Post-Operative: patient was shifted to post-op ward and anal pack was removed after 4 hours and orally started after 6 hours, on next of post-surgery during dressing the discharge from the cavity is collected in sterile container and sent for bacteriology study, sitz bath was advised with Triphala Kwatha twice a day and patient was discharged after 2 days hostipal stay with medication.

\section{Discharge medicines:}

Triphala Guggula BD; Gandhaka Rasayana BD; Abhayarista $10 \mathrm{ml} \mathrm{BD}$ with water; Triphalachoornakashay sitz bath

Follow up: Every alternate day's patient was asked to come for dressing and it took 5 weeks to heal completely later patient was called every month for follow ups for 6 months but no any reoccurrence of abscess or fistula in ano were found.

Results: After regular follow ups for about more than 6 months without any re-occurrence, it gave a satisfaction that the surgical management of perianal abscess followed by Pratisaraniyakshara application yields good result and it not only cures but also minimizes the rate of complication and re-occurrence.

\section{DISCUSSION}

Aerobic culurture yeilds Bacterial growth and the organism isolated

the specimen was collected during I\&D procedure for about $5 \mathrm{ml}$ of pus in sterile container Staphylococcus aureus was the most common isolated bacteria from the pus which was $84.6 \%$ followed by proteus spp was about $16 \%$.

And repeat pus culutre was done by collecting the discharge on $2^{\text {nd }}$ day after the procedure of pratisaraniya kshara application. The aerobic culuture yeilds bacterial growth and the organism isolated are staphylococcus aureus was about $12 \%$ and proteus spp was absent.

Most of the perianal abscess pathology has postulate of crypto anal gland infection cause. Here we adopted incision and drainage followed by PratisaranaKshara application, most of the perianal abscess and open wound around the anal opening are more vulnerable for infection and henceforth reoccurrences chances are more in the form of abscess or fistula in ano. Apamarga Kshara are prepared from herbal drugs and it includes the basic properties of the original herbal drugs. Kshara is predominant with Agnibhuta (fire element) hence having Teekshna property. It consists of SparshaGuna (consistency property) due to its predominant of Vayubhuta (wind element) and hence give quick action. So, above factors clearly state that Kshara is having predominance of Agni and Vayubhuta. Kshara is having Tejobhuta (agni element) property predominantly hence it is having the property of corrosiveness ${ }^{6}$. According to Shushruta Kshara is the most superior procedure among Shastra and Anushastra (sharp instrument and substitute of sharp instrument) because it is having superior qualities like Chedana, Bhedana, Lekhana ${ }^{7}$ etc. So, Khara having Lavana (Salty), Tikta (bitter) Rasa; and Ruksha (dry), Teekshana Guna (properties); Ushna (hot) Viry (Potency); and Katu (Pungent) Vipaka (attributes of drug assimilation $)^{8}$.

\section{CONCLUSION}

The surgical management of perianal Abscess followed by Pratisaraniyakshara application yields good 
result and it not only cures but also minimizes the rate of complication and re-occurrence and with bacteriological study we came to know its Anti-microbial action and suppress the growth of micro-organism and antimicrobial therapy can be avoided. According to Ayurvedic classics Kshara has a property of Krimigna. It is a good therapy and patient satisfactory.

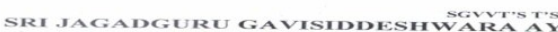

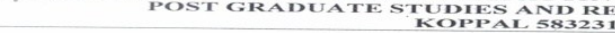

Pt.NAME :Sharanappa

Or Sangamesh MS (A)w

DATE: $07 / 042020$

LABORATORY REPORT

AGE: 36 SEX 36 Mato

Culture Sensitivity Report

Sample for Aerobic Culture: Pus (5m1)

Report: Aerobic culture yields Bacterial Growth and the organism isolated is Staphylococcus aureus
84.6\%, Proteus spp $16 \%$
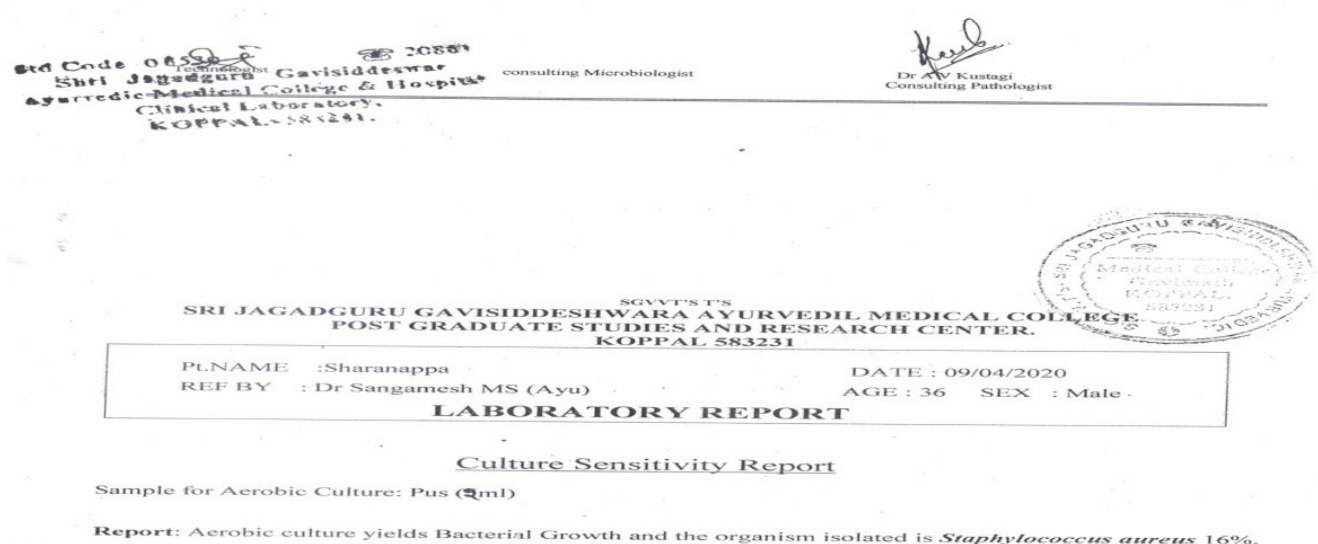

Sto Cind ors?

cinedicul College \& glospiat
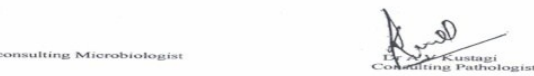


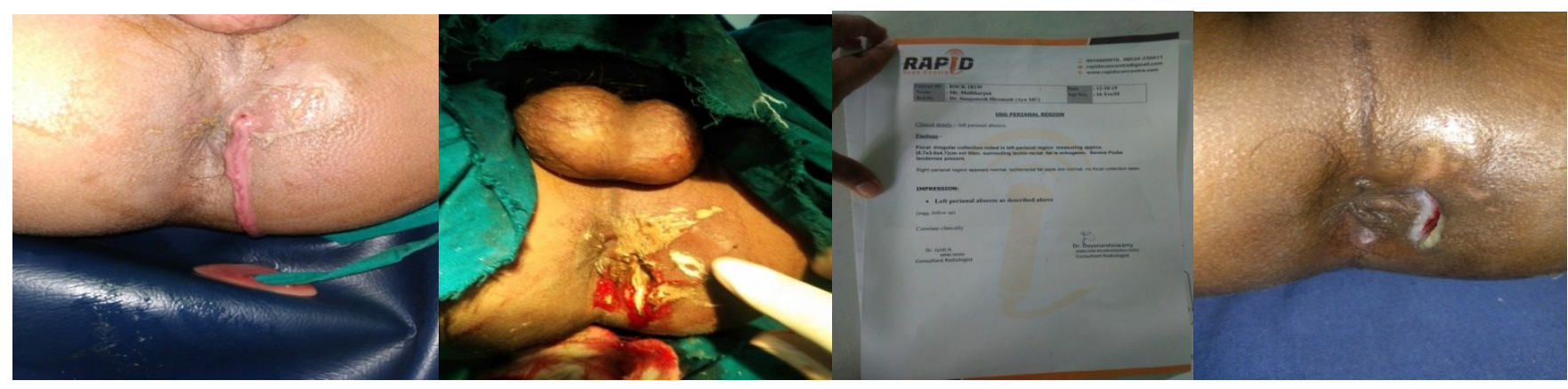

Fig1 perianal Abscess $\quad$ Fig 2 During I \& D

Fig 3 Scanning report

Fig 4 After 15 days

\section{REFERENCES}

1. Somen Das, A Concise textbook of Surgery, 4th edition, published by Dr. S. Das, 2006, p.63.

2. Kaviraj Ambikadutt shastri- SUSHRUTHA SAMHITHA, NIDANA STANA 9/,4 Chowkamba Sanskrit Sanstan Varanasi, part-I, edition 2010 pgno341.

3. Schwartz's Principal of Surgery, $10^{\text {th }}$ edition Copyright (C) 2015 by McGraw-Hill Education publication. The material in this eBook also appears in the print version of this title: ISBN: 978-0-07-179675-0, MHID: 007-179675-4. eBook conversion by code Mantra Version 1.0

4. Kaviraj Ambikadutt Shastri, Sushrutha Samhitha, Chikitsa Stana 16/12, 2010 edition, Part 1, Chowkamba Sanskrit Sanstan, Varanasi, 2010; p.96.

5. P. V. Sharma, Susruta-Samhita, Sutra Sthana 11/5, Revised edition, Chaukhambha Visvabharati, Varanasi, 2004; p.114.

6. P. V. Sharma, Susruta-Samhita, Sutra Sthana 11/5, Revised edition, Chaukhambha Visvabharati, Varanasi, 2004; p.114.

7. P. V. Sharma, Susruta-Samhita, Sutra Sthana 11/3, Revised edition, Chaukhambha Visvabharati, Varanasi, 2004; p.113.

8. P. V. Sharma, Susruta-Samhita, Sutra Sthana 11/5, Revised edition, Chaukhambha Visvabharati, Varanasi, 2004; p.114.

\section{Source of Support: Nil \\ Conflict of Interest: None Declared}

How to cite this URL: Hiremath Sangamesh \& Biradar Vijaykumar: The Evaluation Of Bacteriology In Pre-Post Kshara Karma Of Perianal Abscess - A Case Report. International Ayurvedic Medical Journal \{online\} 2020 \{cited October, 2020 $\quad$ Available from: http://www.iamj.in/posts/images/upload/4944_4948.pdf 